\title{
Partial penectomy after debridement of a Fournier's gangrene progressing with an isolated penile necrosis
}

\author{
Fatih Akbulut, M.D., Onur Kucuktopcu, M.D., Erkan Sonmezay, M.D., \\ Abdulmuttalip Simsek, M.D., Faruk Ozgor, M.D., Zafer Gokhan Gurbuz, M.D.
}

Department of Urology, Haseki Training and Research Hospital, İstanbul

\begin{abstract}
Fournier's gangrene (FG) is a rare and often fulminant necrotizing fasciitis of the perineum and genital region frequently due to polymicrobial infection. This truly emergent condition is typically seen in elderly, diabetic and immune compromised patients. Here, we report an unusual case of FG with isolated glans penis necrosis in a diabetic 77-year-old male patient presented to the emergency department complaining 5 days of pain and darkening of the glans penis. Examination of the patient's glans penis was consistent with FG and included significant erythema and infectious discharge. He was given intravenous antibiotics and emergency debridement was done. On following days, the necrotic area spread to distal parts of both cavernosal areas. Partial penectomy was performed. Isolated penile involvement in FG is very rare. Performing partial penectomy in appropriate cases can save penile length, stop the progression of disease, and increase the quality of life.
\end{abstract}

Key words: Fournier's gangrene; partial penectomy.

\section{INTRODUCTION}

Fournier's gangrene (FG) is a rare and rapidly progressive necrotizing fasciitis of male genitalia, perineal and perianal region leading to sepsis and death, if not rapidly treated. ${ }^{[1,2]}$ FG was first described by Jean Alfred Fournier as necrotizing fasciitis of male genitalia. ${ }^{[3]}$ This urgent disease is generally seen with poor hygiene of genital area of immunosuppressed old patients and patients with diabetes mellitus (DM). ${ }^{[4]}$ In rare cases, penile amputation and orchiectomy is needed. [5] Number of patients with isolated penile involvement is very low.

In this case report, we aimed to present a case of FG with only glans penis necrosis irresponsive to emergency debridement.

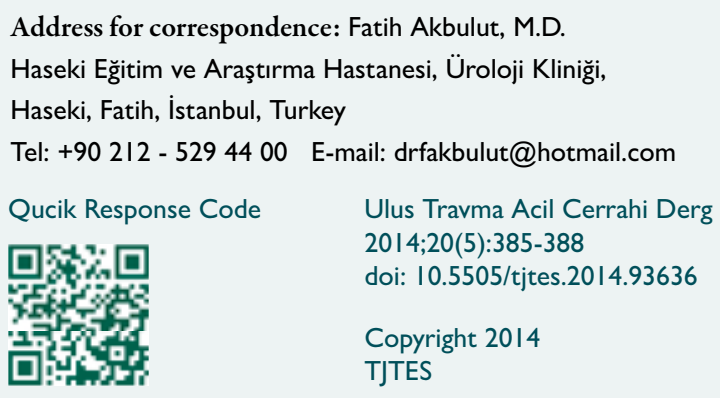

\section{CASE REPORT}

A 77-year-old male patient referred to our emergency clinic with pain, edema and darkening of the glans penis. He indicated that those complaints appeared after insertion of urethral catheter 5 days prior due to acute urinary retention. Physical examination revealed $3 \mathrm{~cm}$ of necrotic and gangrenotic field close to external urethral meatus and infectious discharge nearby the catheter. He had had DM and coronary arterial disease for about 20 years. Both legs were amputated beneath the knees because of DM. Vital signs were: blood pressure: I40/80 mmHg; pulse: 102 bpm; body temperature: 37.0 Celsius and respiration rate was 20. Laboratory tests showed: hematocrit, 29.8; hemoglobin, 9.5 mg/dl; leukocyte, 6600 / uL; C-reactive protein, $147 \mathrm{mg} / \mathrm{dl}$; thrombocyte, I68000/uL; creatinine, $0.90 \mathrm{mg} / \mathrm{dl}$; sodium, $136 \mathrm{mmol} / \mathrm{L}$; potassium, 4.47 $\mathrm{mmol} / \mathrm{L}$; and glucose, $105 \mathrm{mg} / \mathrm{dl}$. Urine tests showed WBC $309 / \mathrm{uL}$ and RBC II8/uL. The patient was diagnosed with isolated penile FG and an emergency debridement of the necrotic areas was planned. Before the operation, the bladder was filled with saline and percutaneous suprapubic cystostomy was inserted by ultrasound guide. Afterwards, the necrotic areas were debrided and samples were collected for pathological and microbiological investigation.

Infectious diseases consultation suggested an empirical treatment of meropenem ( $3 \mathrm{~g} /$ day) and vancomycin (I g/day). Mi- 

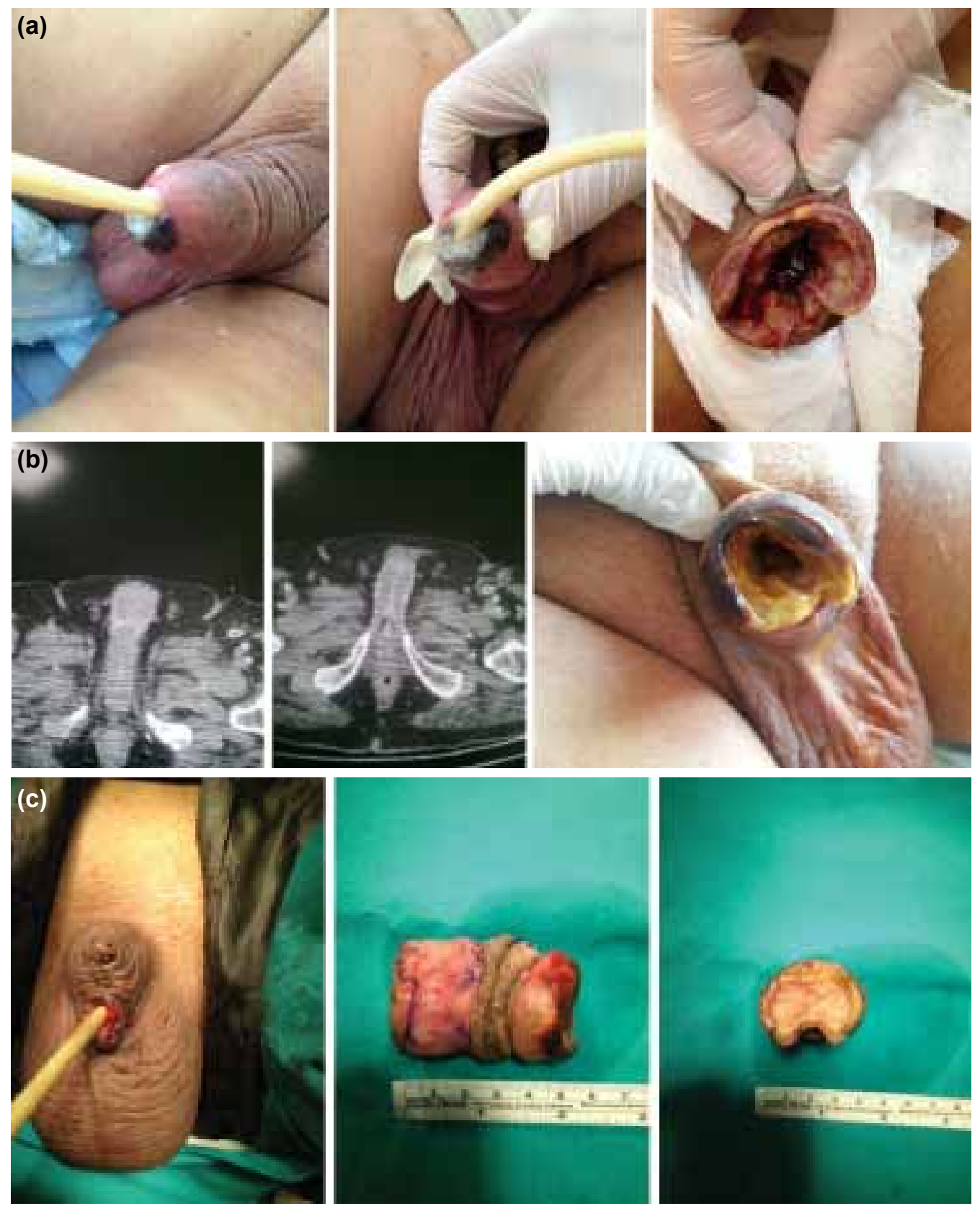

Figure 1. (a) Necrotic fields before the emergent debridement and situation after operation. (b) Spiral pelvic CT and macroscopic view of penis before partial penectomy. (c) Post operative view and macroscopic view of the excised penis part.

crobiological specimen resulted as extended spectrum beta lactamase (ESBL) producing Escherichia Coli (E.Coli) sensitive for meropenem and the existing antibiotic regimen was carried on. During follow-up, the necrotic areas spread to cavernosal tissue. On pelvic computed tomography (CT), necrotic area widened to the distal parts of both corpus cavernosum. Eight days after first operation, partial penectomy was decided to be made.

Penile skin was degloved after marking with sterile pen. By inserting forceps through the hole on the glans penis, the depth of cavernosal necrosis and approximate site of excision was predicted. Penile tourniquet was not needed because of poor blood supply to cavernosal tissue. Dorsal vessel and nerves were sutured and cut. Corpus cavernosum and urethra were separated and urethra was cut $\mathrm{I} \mathrm{cm}$ distal to the penectomy line. Afterwards, both cavernosal bodies were resected. Corporeal ends were sutured continuously by horizontal mattress sutures passing through buck fascia, tunica albuginea and intercavernosal septum. Urethra was spatulated at 12 PM. Penile skin was laid on cavernosal bodies and sutured to the urethral mucosa. Urethral catheter was inserted.

The urethral catheter was taken on post-operative 4th day. 


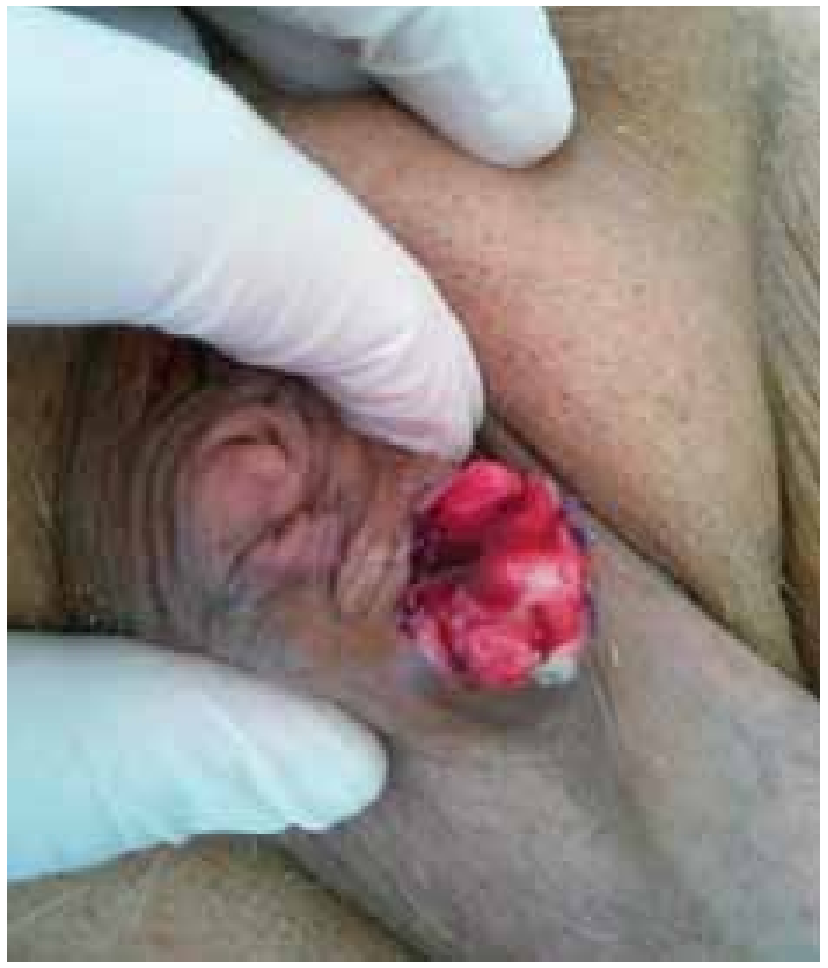

Figure 2. Urethra and penis during discharge from hospital.

Patient had no urinating symptoms. At the end of the 20th day of first referral to the hospital and on the post-operative 12th day of partial penectomy, patient was discharged.

\section{DISCUSSION}

FG is a rare disease accounting less than $0.02 \%$ of hospital admissions and with an incidence of 1.6 of 100.000 male patients. Females are affected very rarely. Mortality rate was reported as $16 \%$ in a study including 1726 FG patients. ${ }^{[6-8]}$

FG is a polymicrobial process starting with a triggering event. In etiology, both aerobic and anaerobic microorganisms play role. Escherichia coli, Streptococcus, Staphylococcus, Enterococcus and Bacteroides strains are the mostly seen bacteria. ${ }^{\left[{ }^{9]}\right.}$ Bacterial infections result in thrombosis and lead to insufficient tissue oxygenation, thus resulting in an anaerobic environment. Heparinase excreted from aerobic bacteria leads to enzymatic destruction of the tissue by anaerobes. The source of infection is usually urogenital and colorectal diseases or traumas of perineal region and scrotum. ${ }^{[10]}$ In our patient, isolated penis involvement of FG occurred after insertion of urethral catheter and Escherichia coli was isolated.

Most common factors facilitating the occurrence of FG are: diabetes mellitus (DM), steroid treatment, chronic alcohol abuse, old age, HIV infection, heart diseases, renal failure, peripheral artery diseases, chemotherapy, and malignancies. DM is the most common predisposing factor but it doesn't affect the mortality rate or the prognosis of the disease. DM, together with chronic alcohol usage, affects the prog- nosis negatively. ${ }^{[1]}$ Our patient had a predisposing factor of 20 years of DM, resulting in his bilateral lower extremities to be amputated.

Laor and colleagues have formed a scoring system named Fournier's Gangrene Severity Index (FGSI) to evaluate the prognosis of FG patients. According to this scoring system, body temperature, pulse, respiration rate, serum sodium, serum creatinine, hematocrit, leukocyte and bicarbonate levels are evaluated. Scores $\leq 5$ are recorded as low, 6-7 as intermediate and $\geq 8$ as high scores. FSGI score $>9$ indicates $75 \%$ death and $\leq 9$ indicates $78 \%$ survival rates. ${ }^{[3]}$ Our patient had a FSGI score of 2 .

Treatment consists of early and aggressive debridement. ${ }^{[5]}$ Empirical broad spectrum antibiotics are given as first choice and can be changed according to the isolated bacteria. ${ }^{[13]} \mathrm{Pa}$ tients without diffuse penile and urethral involvement usually don't need suprapubic catheterization and urethral catheter is usually enough. ${ }^{[7]}$ Patients seldom need penis amputation and orchidectomy is indicated. ${ }^{[5]}$ Hyperbaric oxygen treatment can be useful for the treatment of FG. ${ }^{[13]}$

Early partial penectomy usually decreases morbidity in patients with gangrenous necrosis of glans penis. Chiang et al. ${ }^{[14]}$ performed partial penectomy to five dry gangrenous necrosis cases. In one year follow up, no infection and complication were seen and all patients survived. Three patients could urinate from neourethra and two needed suprapubic catheterization because of benign prostatic obstruction and bed dependency. In our case, partial penectomy was performed and urination from neourethra was good.

Isolated penile involvement in FG is very rare. Performing partial penectomy in appropriate cases can save penile length, stop the progression of disease, and increase the quality of life.

Conflict of interest: None declared.

\section{REFERENCES}

1. Erol B, Tuncel A, Hanci V, Tokgoz H, Yildiz A, Akduman B, et al. Fournier's gangrene: overview of prognostic factors and definition of new prognostic parameter. Urology 2010;75:1193-8. CrossRef

2. Anchi T, Tamura K, Inoue K, Ashida S, Yasuda M, Kataoka S, et al. Localized Fournier's gangrene of the penis: a case report. [Article in Japanese] Hinyokika Kiyo 2009;55:153-6. [Abstract]

3. Laor E, Palmer LS, Tolia BM, Reid RE, Winter HI. Outcome prediction in patients with Fournier's gangrene. J Urol 1995;154:89-92. CrossRef

4. Heiner JD, Eng KD, Bialowas TA, Devita D. Fournier's Gangrene due to Masturbation in an Otherwise Healthy Male. Case Rep Emerg Med 2012;2012:154025.

5. Fajdic J, Gotovac N, Hrgovic Z. Fournier gangrene: our approach and patients. Urol Int 2011;87:186-91. CrossRef

6. Sorensen MD, Krieger JN, Rivara FP, Broghammer JA, Klein MB, Mack $\mathrm{CD}$, et al. Fournier's Gangrene: population based epidemiology and outcomes. J Urol 2009;181:2120-6. CrossRef 
7. Koukouras D, Kallidonis P, Panagopoulos C, Al-Aown A, Athanasopoulos A, Rigopoulos C, et al. Fournier's gangrene, a urologic and surgical emergency: presentation of a multi-institutional experience with 45 cases. Urol Int 2011;86:167-72. CrossRef

8. Eke N. Fournier's gangrene: a review of 1726 cases. Br J Surg 2000;87:718-28. CrossRef

9. Martínez-Rodríguez R, Ponce de León J, Caparrós J, Villavicencio H. Fournier's gangrene: a monographic urology center experience with twenty patients. Urol Int 2009;83:323-8. CrossRef

10. Jeong HJ, Park SC, Seo IY, Rim JS. Prognostic factors in Fournier gangrene. Int J Urol 2005;12:1041-4. CrossRef
11. Shyam DC, Rapsang AG. Fournier's gangrene. Surgeon 2013;11:222-32.

12. Yanar H, Taviloglu K, Ertekin C, Guloglu R, Zorba U, Cabioglu N, et al. Fournier's gangrene: risk factors and strategies for management. World $\mathrm{J}$ Surg 2006;30:1750-4. CrossRef

13. Janane A, Hajji F, Ismail TO, Chafiqui J, Ghadouane M, Ameur A, et al. Hyperbaric oxygen therapy adjunctive to surgical debridement in management of Fournier's gangrene: usefulness of a severity index score in predicting disease gravity and patient survival. [Article in Spanish] Actas Urol Esp 2011;35:332-8. [Abstract] CrossRef

14. Chiang IN, Chang SJ, Kuo YC, Liu SP, Yu HJ, Hsieh JT. Management of ischemic penile gangrene: prompt partial penectomy and other treatment options. J Sex Med 2008;5:2725-33. CrossRef

\section{OLGU SUNUMU - ÖZET}

\section{Fournier gangreni debridmanı sonrası devam eden}

\section{izole penis nekrozunda parsiyel penektomi}

\section{Dr. Fatih Akbulut, Dr. Onur Kucuktopcu, Dr. Erkan Sonmezay, Dr. Abdulmuttalip Simsek, Dr. Faruk Ozgor, Dr. Zafer Gokhan Gurbuz}

Haseki Eğitim ve Araştırma Hastanesi, Üroloji Kliniği, İstanbul

Fournier gangreni (FG) perine ve genital bölgenin nadir görülen ve sıklıkla kötü seyirli nekrotizan fasiitidir. Genellikle polimikrobiyal enfeksiyona bağlıdır. Acil olan bu durum sıklıkla yaşlı, diyabetik ve immün sistemi zayıf hastalarda görülür. Bu yazıda, FG'nin nadir bir formu olan izole glans penis tutulumu ile başvuran bir hasta sunuldu. Yetmiş yedi yaşında erkek hasta beş gündür glans peniste ağrı ve siyah renk değişikliği ile başvurdu. Glans penisin muayenesinde belirgin eritem ve iltihabi akıntı mevcuttu ve görünümü FG ile uyumlu idi. Antibiyoterapisi başlanıp erken debridmanı yapıldı ancak takibin ilerleyen günlerinde nekrotik bölge kavernozal cisimlerin distaline doğru ilerledi. Hastaya parsiyel penektomi yapıldı. FG'de izole penis tutulumu nadir olarak görülür ve uygun olgularda zamanında parsiyel penektomi yapmak kalan penis boyutunu koruyup, hastalığın ilerlemesini önleyerek hayat kalitesini artırabilir.

Anahtar sözcükler: Fournier gangreni; parsiyel penektomi.

Ulus Travma Acil Cerrahi Derg 20।4;20(5):385-388 doi: 10.5505/tjtes.20I4.93636 